\section{SANDWORT (Arenaria peploides) ON FRESHWATER BEACH, BEVERLY LAKE, KEEWATIN}

by Ernie Kuyt, Fort Smith, N.W.T.

On July 24, 1961 while examining wolf tracks near the carcass of a bull caribou on the sandy beach south of the Canadian Wildlife Service cabin on Beverly Lake, Keewatin, my attention was drawn to a fleshy-leaved plant on the shore. The plant was quite common in the immediate area, growing in a matted form with stems much branched and frequently tinged with light purple. Flowers were small, white and borne on the terminal parts of the stems. Seed capsules, light brown and globular, were also observed. I had not previously found the plant in the Lookout Point area, Thelon River, about 100 miles to the west, where most of my plant collections have been made. Upon checking A. E. Porsild's "Illustrated Flora of the Canadian Arctic Archipelago" (1957), I tentatively identified the plant as Arenaria peploides. The distribution map of the Sandwort Arenaria peploides var. diffusa indicates its occurrence is limited to seashores. A duplicate specimen was forwarded to the National Museum of Canada where Porsild verified my identification.

\section{SHAGGY MANE MUSHROOMS EATEN BY CRICKETS}

\author{
by Joyce Deutscher, Regina
}

For the past four years I have collected hundreds of Shaggy Mane (Coprinus) mushrooms for eating and have always congratulated myself that they were free from insect damage. I was surprised then to find that mushrooms collected on September 19, 1964 along Highway No. 19 near Lawson showed signs of having had holes eaten through the cap before the mushroom appeared above the ground. In one instance I saw a black field cricket scurrying away from a mushroom. My suspicions were confirmed when I found a cricket in a hole in the side of a freshly eaten mushroom. This mushroom was not yet above the ground.

I have collected Shaggy Manes as far north as North Battleford and The Pas and as far south as Lawson but this is the first time I have found any evidence of insect damage.

\section{SCARLET GAURA OR BUTTERFLY WEED}

by Keith F. Best, Swift Current

One of the most interesting plants of the open prairies is the Scarlet Gaura (Gaura coccinea Pursh). Common on dry prairies and hillsides across the southern portion of the area, this perennial grows from four to 12 inches in height. The muchbranched stems generally lie prostrate on the ground with the tips reaching upwards. The numerous small leaves have no stalks, range from wavymargined to toothed, and are covered with short grey hairs. The drier the soil in which this plant grows, the heavier is this protective covering.



Scarlet Gaura generally flowers during the latter part of June, and the flowers are in terminal racemes. When the buds first open, there appear four pure white petals which quickly turn pink, and then become a brilliant scarlet. Thus we often find flower clusters with white flowers above and bright scarlet clusters beneath. In addition to this startling color scheme, the flowers have eight prominent stamens with white filaments and large brick-red anthers, giving the flower the appearance of a butterfly. The fruits are small capsules about one-quarter inch long and contain from one to four seeds. 